\title{
KSR1 Gene
}

National Cancer Institute

\section{Source}

National Cancer Institute. KSR1 Gene. NCI Thesaurus. Code C24537.

This gene plays a role in cell growth and differentiation. 